\title{
Детерминанты социально-политической активности современной молодежи
}

\author{
Наталия В. Усова \\ ФГБОУ ВО «Саратовский национальный исследовательский государственный универ- \\ ситет имени Н. Г. Чернышевского», г. Саратов, Российская Федерация \\ E-mail: usovanatalia@mail.ru
}

\begin{abstract}
Аннотация
Введение. Новизна исследования обусловлена тем, что на основе системноАиахронического подхода преАложена многоуровневая модеАь социально-поАитической активности молодежи. Разработан и применен новый метоАический ИнстрУментарий в виАе опросника социа^ьно-политической актИвности Мо^оАежи, измеряющего степень активности, преднамеренности и Аеструктивности в социально-политической жизни общества.
\end{abstract}

Метолы. Использовались качественные и количественные методы сбора данных, анкеты и стандартизированные опросники. Аанные обрабатывались с помощью контент-анализа и вторичной математико-статистической обработки.

Результаты и их обсужАение. ПерехоА от уровня социально-политической пассивности к уровню социально-политической активности Аетерминирован: возрастом, уровнем образования и Аохола, профессиональной Аеятельностью, сорормированностью патриотического сознания, отсутствием политического индрантилизма и мотивации к Аостижению успеха и власти, отсутствием напряжения в жилищно-бытовых условиях, неудовлетворенностью сфрерой Аосуга и супружескими взаимоотношениями, а также повышенной концентрацией на эмоциях. ПерехоА от Аеструктивной к конструктивной форме социально-политической активности обусловлен: АОминированием ценности инАивиАуаАизма И инАИвИАуаАИстической ориентацией, потребительским характером организации Аосуга и низким уровнем Аоверия по отношению к власти, выраженной мотивацией к в^асти и отсутствием мотивации к аффоилиации, высоким уровнем уловлетворенности образованием и содержанием профрессиональной деятельности, эмоциональным напряжением в сорере жилищно-бытовых условий и обстановки в обществе, а также такими поведенческими стратегиями, как слерживание, подавление и употребление успокоительных средств. Перехол от непреднамеренной к преднамеренной социально-политической активности осуществляется с развитием рефрлексии, социально-политической компетентности, политической социализацией в це^ом, а также выраженной мотивацией к власти и успеху, неудовлетворенностью условиями проведения Аосуга и солержанием работы, но при этом отсутствием 
напряжения в жилищно-бытовых условиях и ск^онностью к п^анированию. Разное сочетание Аетерминант порожАает вариации субъектов социально-политической активности Аиапазон которых представлен соотношением степени активности, преднамеренности и конструктивности ее проявлений. На основе Аанного по^ожения представлена характеристика разных типов социально-политической активностИ МОАОАОГО поколения.

\section{КАючевые слова}

системно-Аиахронический поАхоА, социально-политическая активность, социально-политическая пассивность, мотивация, рефлексия, Аоверие к власти, эмоциональное напряжение, политический инфантилизм, патриотизм, социально-политическая компетентность

\section{Основные положения}

- социально-политическая активность современной молодежи является Сложноорганизованным, подчиненным жизненно важным целям, постоянно и Аинамично функционирующим явлением, обусловленным многочисленной системой Аетерминации, изучение которой Аолжно производиться на основе системно-Аиахронического поАхоАа;

- системно-Аиахронический поАхоА Аиктует необходимость учета уровня, направ^енности и фрормы социально-политической активности современной молоАежи; - система социально-политической активности является перерастающей в своем развитии себя и переходящей в Аругую систему; в качестве Аетерминант Аанного перехода считаем возможным рассмотреть мотивацию, рефлексию собственных Аействий, уровень Аоверия к власти, сферу эмоционального напряжения и способы совлаАания со стрессом, ценностные преАпочтения, политический инорантилизм, уровень патриотизма и социально-политическую компетентность.

\section{Для цитирования}

Усова Н. В. Детерминанты социально-политической активности современной молодежи // Российский психологический журнал. 2019. Т. 16, № 2. С. 164-188. doi: 10.21702/ rpj.2019.2.9 
UDC 159.923:316.6

doi: $10.21702 /$ rpj.2019.2.9

\title{
Determinants of Socio-political Activity of Contemporary Youth
}

\author{
Nataliya V. Usova \\ Saratov State University, Saratov, Russian Federation \\ E-mail: usova natalia@mail.ru
}

\begin{abstract}
Introduction. This paper presents a hierarchical model of socio-political activity of contemporary youth based on the system-diachronic approach. The author developed and tested a new diagnostic tool for measuring the degree of activity, intentionality, and destructiveness in subjects of social, public, and political life-a questionnaire on young people's socio-political activity.
\end{abstract}

Methods. The study employed qualitative and quantitative data collection methods, standardized questionnaires, and inventories. The data collected were processed using content analysis and secondary mathematical and statistical analysis.

Results. Age, income, education level, professional activity, patriotic consciousness, absence of political infantilism, absence of achievement and power motivations, satisfaction with living conditions, dissatisfaction with leisure sphere and partner relationships, and focusing on emotions together determine the transition from sociopolitical passivity to socio-political activity. The transition from a destructive form of socio-political activity to a constructive one is determined by dominance of values of individualism and individualistic orientation, consumption in leisure, low confidence in authorities, high power motivation, absence of affiliation motivation, high satisfaction with education and professional activity, emotional stress caused by living conditions and social climate, and certain behavioral strategies, including repression, suppression, and use of sedatives. The transition from an unintentional socio-political activity to an intentional one is associated with reflection, socio-political competence, political socialization, high achievement and power motivations, dissatisfaction with leisure sphere and professional activity in the absence of emotional stress caused by living conditions, and a high propensity to plan.

Discussion. Various combinations of determinants form the types of subjects of sociopolitical activity who are characterized by different correlations among the degree of activity, intentionality, and of the constructiveness of its manifestations. This thesis enabled the author to describe characteristics of different types of young people's socio-political activity. 


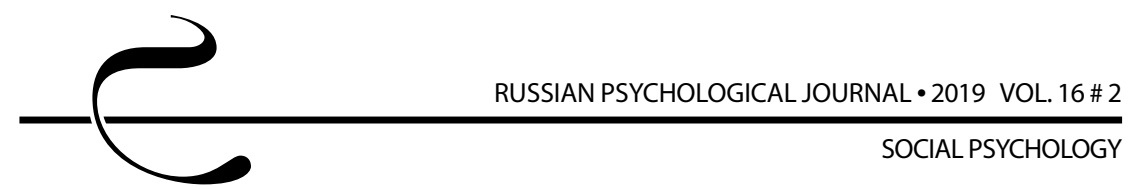

\section{Keywords}

system-diachronic approach, socio-political activity, socio-political passivity, constructive/ destructive, intentional/unintentional, motivation, reflection, confidence in authorities, emotional stress, political infantilism, patriotism, socio-political competence

\section{Highlights}

- Socio-political activity of contemporary youth is a complex continuous and dynamic phenomenon which is determined by vital goals and a multicomponent system of determinants.

- Socio-political activity of contemporary youth should be investigated using the system-diachronic approach, which takes into account its levels, directions, and forms.

- During its development, the system of socio-political activity transforms itself into another system. Individuals' motivation, reflection of their own actions, level of confidence in authorities, emotional stress, strategies for coping with stress, values-based preferences, political infantilism, level of patriotism, and socio-political competence appear to be determinants of such a transition.

\section{For citation}

Usova, N.V. (2019). Determinants of Socio-political Activity of Contemporary Youth. Rossiiskii psikhologicheskii zhurnal (Russian Psychological Journal), 16(2), 164-188. (in Russ.). doi: 10.21702/rpj.2019.2.9

Original manuscript received 18.10.2018

\section{Введение}

Социально-политическая активность молодежи достаточно изменчива в зависимости от обстановки в современном обществе. При этом эффективность и перспективы развития современного государства во многом обусловлены вовлеченностью молодежи в социально-политические процессы. Молодежь является особой социальной группой, обладающей целым набором специфических характеристик. Именно от активности молодежи во многом зависит будущее нашей страны. Проблемы социально-политической активности молодежи занимают важнейшее место в системе общественных отношений и требуют детального изучения со стороны исследователей (Криворучко и Щербакова, 2013).

Сегодня в социально-психологических и социально-политических исследованиях можно найти большое количество исследований, всесторонне раскрывающих феномен социально-политической активности. Проведенный анализ имеющихся разработок позволил нам выявить существенный нюанс, не позволяющий говорить о достаточности имеющихся теорий. Так, 
например, большинство исследований основаны на линейном описании социально-политической активности, что не позволяет авторам в полной мере учитывать ее сложный, многоуровневый и нелинейный характер (Морозова, 2015; Левкина, 2016; Грачева, 2016; Чолпонкулова, 2018; Баранова и Костенко, 2014; Васильева, Полтавская и Левковская, 2015; Зайцева, 2016; Albertazzi \& Mueller, 2013; Azzi, Chryssochoou, Klandermans, \& Simon, 2011; Barrett \& Zani, 2015; Craig \& Richeson, 2014; Bot \& Verkuyten, 2018; Hoyt \& Parry, 2018).

С нашей точки зрения, для решения данного вопроса значительно целесообразнее опереться на системно-диахронический подход, позволяющий понять не только характер происходящих во времени изменений, но и раскрывающий противоречивую согласованность становления различных (разноуровневых) инстанций, те внутренние (и латентные) изменения, которые создают основу для развития всей системы социально-политической активности (Шамионов, 2013; Арендачук, 2018; Заграничный, 2018).

Изучение содержательных характеристик социально-политической активности в историческом масштабе и масштабе эпохи однозначно имеет свою особую специфику, но при этом не становится принципиально иным в силу имеющихся устойчивых и доказанных многолетним опытом элементов. Отсюда следует, что исследование и анализ трансформаций заявленного феномена представляют научный интерес с точки зрения разработки обобщающей теории социально-политической активности молодежи, основанной на применении системно-диахронического подхода.

Применение системно-диахронического подхода к исследованию социально-политической активности личности позволит нам изучить данный феномен в реальном временном промежутке и на необходимом уровне психологического анализа с учетом целостной системы детерминант. Мы считаем, что применение системно-диахронического подхода в исследовании социально-политической активности позволит наиболее адекватно описать данный феномен, определить новые основания и детерминанты ее развития. Забегая несколько вперед, отметим, что под детерминантами социально-политической активности мы понимаем движущие силы, побуждающие личность к активной социально-политической деятельности и одновременно способные формировать или трансформировать эту активность, задавая ее направление и формы (Васильева и др., 2015).

За единицу психологического анализа мы считаем целесообразным взять систему взаимоотношений между социально-политической средой и личностью, как структурно сложноорганизованную, динамично функционирующую, подчиненную важным целям и сочетающую в себе возможность учесть многочисленные детерминации. 
В соответствии с системно-диахроническим подходом к исследованию социально-политической активности мы определили следующие единицы анализа: формы, направления, детерминанты и уровни сформированности социально-политической активности, а также особенности взаимодействия личности и социально-политической среды.

\section{Теоретическое обоснование исследования}

Анализ социально-политической активности, с нашей точки зрения, должен идти в трех направлениях.

Первое направление касается выявления детерминант уровня социально-политической активности, вектор которой располагается в диапазоне между социально-политической пассивностью и социально-политической активностью.

Для более глубокого понимания активности необходимо затронуть диалектическую противоположность социальной активности, которой выступает социальная пассивность. В самом широком смысле пассивность можно рассматривать как стиль поведения личности, проявляющийся в бездеятельности. Социальная пассивность является достаточно распространенным явлением в современном обществе. Пассивность есть нежелание, неспособность человека участвовать в чем-либо и преодолевать сложившиеся обстоятельства и собственное безразличие (П. И. Куконков и И. П. Куконков, 2013; Федотова, 2005).

Согласно Кожевникову (1994), деятельность граждан или социальных систем не бывает абсолютно пассивной либо активной. По его мнению, «когда речь идет об активных социальных субъектах, то нужно иметь в виду превалирование их социальной деятельности в каком-то срезе общественной жизни» (с. 22); «социальная активность - это свойство социального субъекта, обладающего сознанием, способностью предвидеть возможные последствия своих действий, проявляемое во взаимодействии с социальной средой посредством самодеятельности, т. е. деятельности, не навязываемой извне, направленной на удовлетворение личных и общественных потребностей и интересов» (с. 25). Формирование основных идей персонализации индивида в поиске способов и средств удовлетворения потребностей быть личностью происходит под влиянием основных факторов развития социальной активности человека. В качестве таких факторов Петровский и Ярошевский (1998) обозначили возрастной фактор, уровень развития группы в обществе. Антропологическая психология в качестве основного фактора развития активности предлагает нам рассматривать высшее интегративное образование человека - человеческую субъективность (Слободчиков и Исаев, 2013).

Стремление активно участвовать в политических процессах, отстаивать свои политические права и интересы в политологии называется «политической 
активностью». Политическая активность молодежи по средствам объединения в различные организации и группы по интересам может происходить, с одной стороны, с целью защиты экономических и иных (нематериальных) ценностей, а с другой, с целью реализации таких задач, при которых каждый индивид отстаивает не свои интересы как члена общества, а интересы определенной референтной группы, выступая ее представителем.

В психологии для описания политических явлений введена категория политической деятельности, которая, как отмечает Юрьев, является высшим проявлением политической жизни человека. Деятельность, по определению Суходольского (2008), предполагает воплощение в себе всех достижений человечества по организации собственной активности.

Рассмотрим политические явления, дифференцируя их по признаку деятельности. Первый уровень - деятельность, под которой понимается общая физическая и психическая активность человека, регулируемая сознательной целью. Сюда можно отнести такое политическое явление, как борьба за ясное, полное, человеческое сознание. Второй уровень - работа, подразумевающая осуществление возможностей интеллекта субъекта политики, его способности осуществлять физические и психические затраты для получения желаемого эффекта. Третий уровень - поведение, понимаемое как система реакций на стимулы политического характера. Сюда относится участие в поиске, создании, распределении жизненных ресурсов. Четвертый уровень - активность, как способность осуществлять политическую деятельность, работу или политическое поведение (Киричек, 2011).

В зависимости от уровня активности, преобладающих форм, а также конвенциональности и неконвенциональности политического участия можно выделить следующие типы политических групп (Киричек, 2011; Kaase \& Marsh, 1979):

1. Неактивные. Политическая активность минимальна, в некоторых случаях по средствам дополнительной стимуляции индивиды могут принять участие в петициях и выборах.

2. Конформисты. В целом избегают непосредственного участия в политической жизни, но демонстрируют более активное участие в конвенциональных формах.

3. Реформисты. Участвуют преимущественно в конвенциональных формах, используют законные формы политического протеста - демонстрации, бойкоты.

4. Активисты. Наиболее активно участвуют в политической жизни, используют преимущественно конвенциональные формы активности.

5. Протестующие. По уровню активности они похожи на реформистов и активистов, однако отличаются от них тем, что участвуют в политическом процессе преимущественно в неконвенциональных формах. 
Социально-политическая пассивность, таким образом, - это стиль поведения личности, проявляющийся в бездеятельности, безучастности, безынициативности, безразличии человека к социально-политической жизни страны. Социально-политическая активность понимается нами как деятельное отношение личности к социально-политической жизни страны, проявляющееся в способности производить социально-политические преобразования.

Второй актуальной проблемой исследования социально-политической активности личности является изучение ее направленности в диапазоне преднамеренность/непреднамеренность.

В зависимости от роли, которую играет субъект политической активности, можно выделить автономное и мобилизованное участие в политических явлениях (Киричек, 2011). В случае автономного участия индивид действует, принимая решение самостоятельно, а в случае мобилизованного участие осуществляется под давлением других субъектов политики или под их влиянием, приводящим к трансформации собственных предпочтений индивида.

Теоретический анализ и обобщение научно-исследовательских данных показали, что изучение социально-политической активности молодежи сегодня является приоритетной задачей социальной психологии; особое значение здесь приобретают вопросы ее личностной регуляции, в частности, ее преднамеренности/непреднамеренности. Опираясь на концепции исследователей, занимающихся вопросами осознанности, произвольности и опосредованности психики (Выготского, Узнадзе, Леонтьева, Егоровой, Панова, Страховой, Шамионова, Эльконина, Ситарова, Маралова, Маланова), мы выделили главные отличительные признаки направленности социально-политической активности. Выявленные критерии и признаки преднамеренной и непреднамеренной социально-политической активности представлены в таблице 1.

Вышесказанное позволяет нам говорить о том, что социально-политическая активность, с одной стороны, может быть преднамеренной, т. е. заранее обдуманной, четко спланированной и детерминированной внутренними факторами личности, а с другой - непреднамеренной, т. е. без заранее продуманной цели, спонтанной, детерминированной внешними обстоятельствами или другими людьми.

Третье направление исследования социально-политической активности личности касается изучения ее конструктивной и деструктивной форм проявления. Молодежь, будучи субъектом социально-политической активности, не всегда осознает собственный потенциал и возможные последствия своей социально-политической позиции. Помимо того, что сознание молодого человека характеризуется определенной восприимчивостью, способностью перерабатывать и усваивать большое количество разнообразной информации, 
в данный возрастной период также развивается и критичность мышления со стремлением дать собственную оценку разным социально-политическим явлениям. Молодые люди стараются найти подходящие аргументы и оригинальные решения социально-политических задач. Поиск решений для важнейших жизненных задач, с одной стороны, сопровождается активной ценностно-созидательной деятельностью, а с другой - осложняется недостаточным опытом практической деятельности и неполной включенностью субъекта в систему социально-политических взаимоотношений. В силу этого в поведении молодого поколения легко прослеживаются противоречивые тенденции - стремление к общению и уход, отрешенность от внешнего мира, стремление к идентификации и обособление, подражание и отрицание общепринятых норм, конформизм и негативизм.

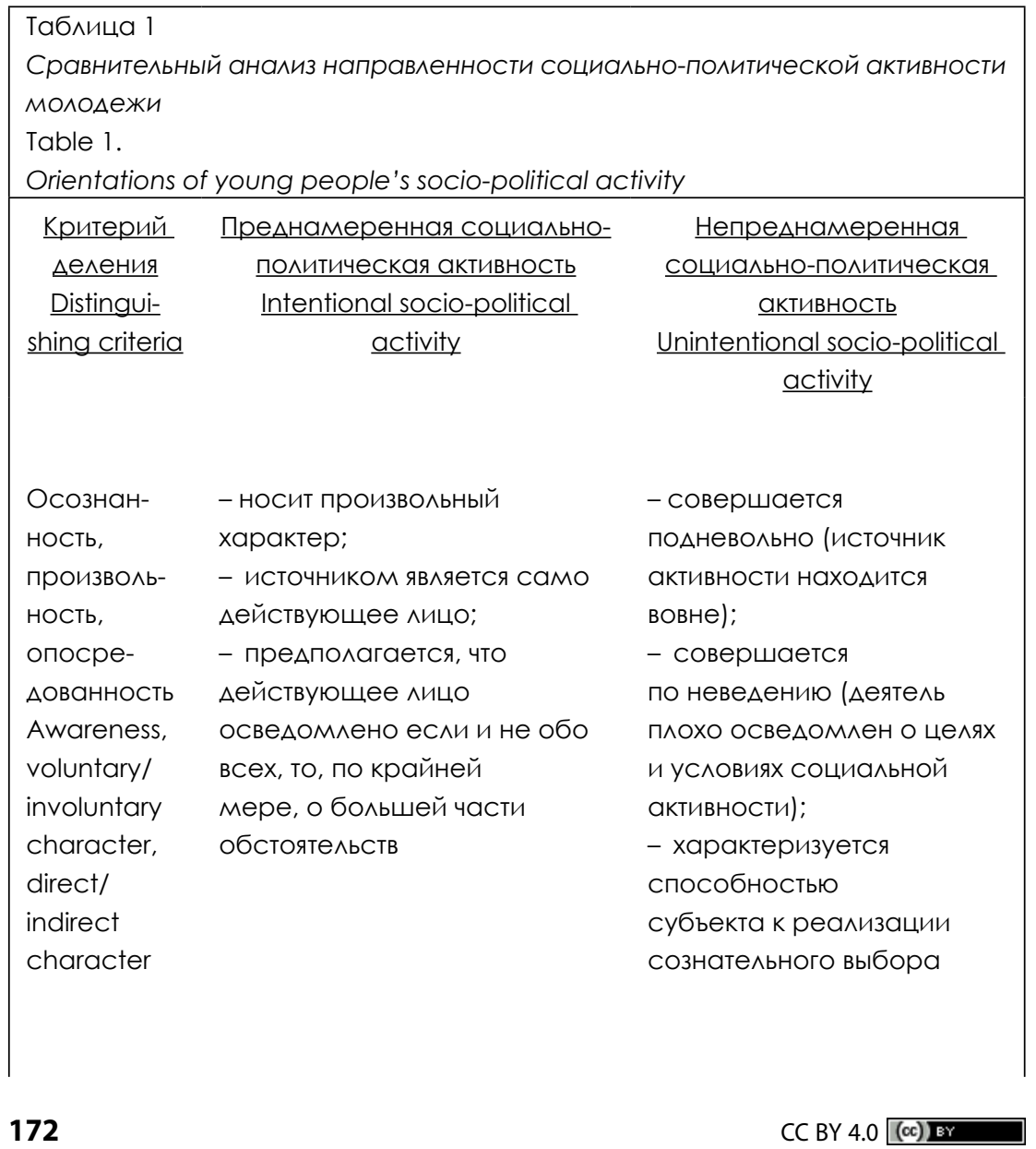




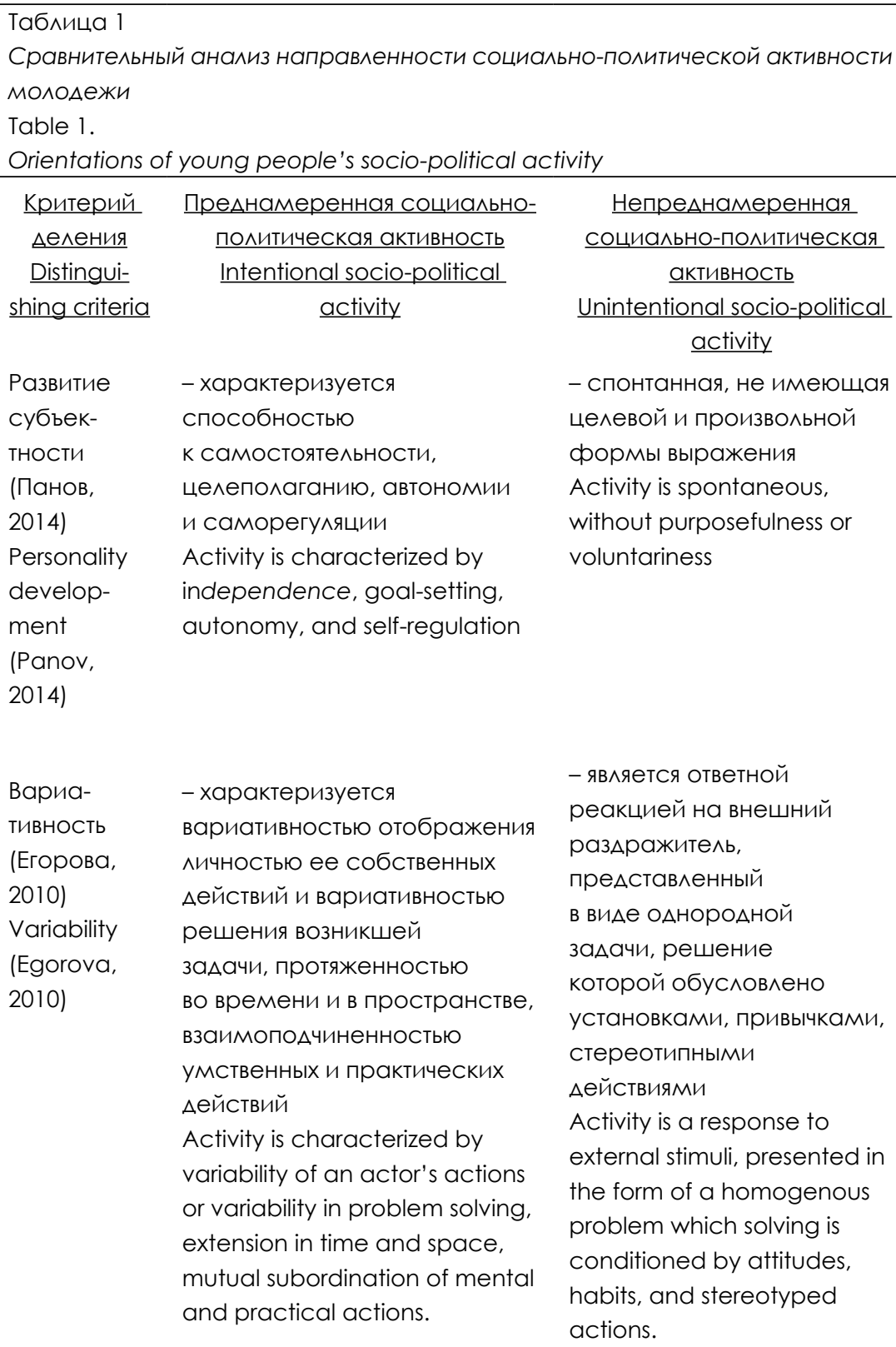




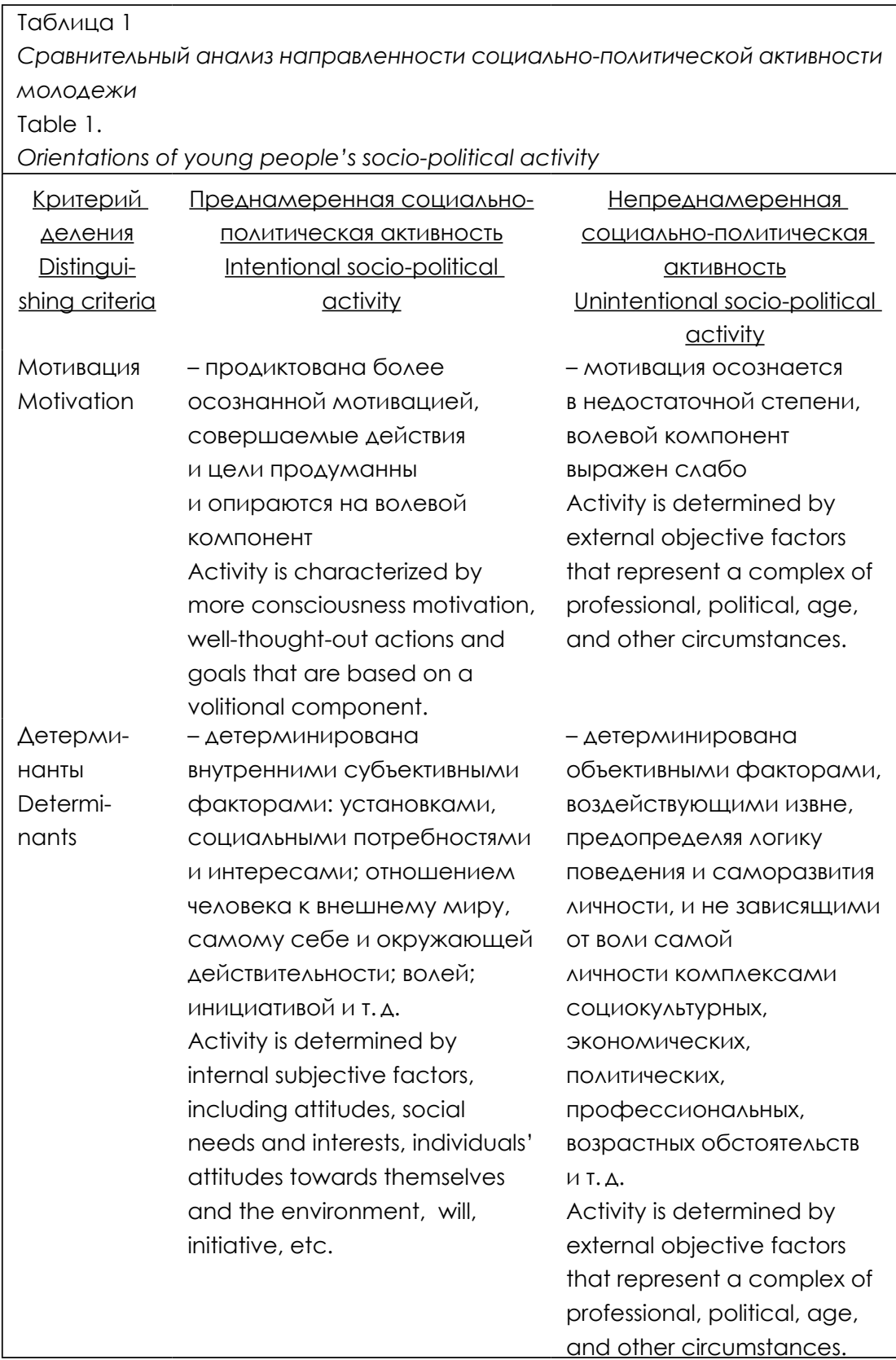


Вышеперечисленные особенности позволили Савастьиной и Осиповой (2015) говорить о конструктивной (созидающей) и деструктивной (разрушающей) формах социально-политической активности современной молодежи. При этом, как утверждает автор, в деструктивных формах проявления активности, например «участие в протестах» и «участие в дворовых группировках», молодежь участвует неохотно и, в некоторой степени, готова к отрицанию негативных, протестных форм проявления своих позиций, конструктивному диалогу и тесному взаимодействию с субъектами государственного и муниципального управления.

Деструктивное поведение личности детерминировано сложным взаимодействием биологических (генетически обусловленные нервные и гуморальные механизмы развития), психологических (личностные характеристики человека) и социокультурных факторов (условия социализации) (Алфимова и Трубников, 2000; Лысак, 2006; Сысоева, Куликова, Малюченко, Тоневицкий и Иваницкий, 2010). Новые элементы в конкретизацию механизмов формирования деструктивных форм поведения человека вносит исследование Мулик, Антонова, Улесиковой и Шатыр (2016). Авторы подчеркивают, что выраженность деструктивной поведенческой активности обусловлена бессознательной мотивацией, причем у женщин она подкрепляется такими свойствами личности, как гипертимность и демонстративность, а у мужчин - негативными эмоциями и повышенной агрессивностью.

Деструктивная социально-политическая активность возникает в ситуации социально-политического напряжения, когда в обществе происходит утрата жизненных ориентиров и смыслов, в ситуациях, сопровождающихся состоянием фрустрации. Наиболее часто встречаются такие формы деструктивной социально-политической активности, как участие в акциях, направленных на разрушение социально-политических институтов, общества и государства в целом, несанкционированные государством проявления насилия, вандализма и нигилизма (П. И. Куконков и Лубяной, 2013). П. И. Куконков и И. П. Куконков (2013) рассматривают деструктивную социальную активность как самодеятельность, разрушающую социальную систему, основной целью которой является «выход потенциала социальной напряженности за границу обеспечения существенных интересов социального субъекта, включение в ее ареал “случайных" объектов» (с. 40). Подобная «самодеятельность» ведет к постепенной утрате социальным субъектом способности приспосабливаться к изменяющимся условиям; со временем деструктивная социальная активность становится способом существования ее субъекта (П. И. Куконков и Лубяной, 2013).

Конечно, конструктивная и деструктивная формы социально-политической активности обусловлены многофакторной и сложносоставной системой детерминант, выявление которых позволит предупредить и сменить вектор их направленности. 
Вышеописанное позволяет нам говорить о том, что деструктивная социально-политическая активность рассматривается нами как разрушительная, сопровождающаяся распадом структурных отношений, организационных связей, функциональных зависимостей в социально-политической организации государства, тогда как конструктивная социально-политическая активность - это такой подход к социально-политической жизни государства, который направлен на установление и/или восстановление продуктивных взаимосвязей в системе социально-политической жизни общества.

Таким образом, предложенная в данной статье модель социально-политической активности молодежи раскрывается нами через многоуровневую конфигурацию (рис. 1), включающую учет:

1. Степени включенности личности в систему социально-политических отношений. Данный вектор отражает степень пассивности/активности в социально-политической жизни общества.

2. Направления социально-политической активности, отражающего линию движения в сторону осознанности и преднамеренности ее проявления.

3. Формы, отражающей влияние социально-политической активности на личность, общество и социально-политическую систему в целом. Данный вектор характеризует социально-политическую активность с точки зрения ее конструктивного и деструктивного характера проявления.

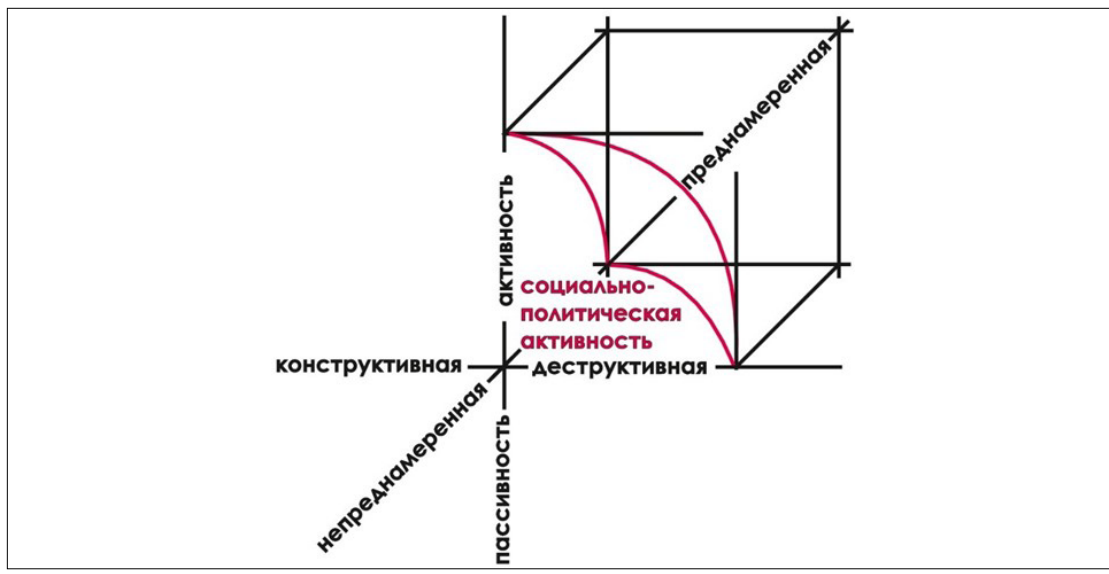

Рисунок 1. Социально-политическая активность в контексте системноАиахронического поАхола

Figure 1. Socio-political activity in the context of the system-diachronic approach 


\section{Методы}

Эмпирическое исследование социально-психологических детерминант социально-политической активности производилось с помощью специально разработанного опросника исследования, включающего учет качественных и количественных данных, отражающих пассивность/активность, преднамеренность/непреднамеренность, конструктивность/деструктивность молодежи в системе социально-политической жизни (авторский опросник СПАМ) (Усова, 2018b), а также стандартизированных опросников: опросника совладания со стрессом COPE (Carver, Scheier, Weintraub) в русскоязычной адаптации Гордеевой, Осина, Рассказовой, Сычева, Шевяховой; методики определения уровня рефлексивности (по Пономаревой); экспресс-диагностики уровня социальной фрустрированности (Вассермана); диагностики мотиваторов социально-психологической активности личности. В программе исследования также использовались результаты глубинного интервью и шкалирования ценностной и мотивационной систем, особенностей поведения в ситуации эмоционального напряжения, доминирующих чувств и состояний, социально-политической компетенции (Усова, 2018а). Все полученные данные подвергались корреляционному анализу с последующей интерпретацией.

В исследовании принимали участие испытуемые в возрасте от 15 до 25 лет. Социально-демографические характеристики выборки: верхняя возрастная группа от 23 до 25 лет - 42\%, средняя от 18 до 22-34 \% и нижняя от 15 до 17 лет - $24 \%$ от общей численности молодежи; по половой принадлежности $57 \%$ - женщины, 43 \% - мужчины; по семейному положению $62 \%$ не состоящие в браке, 28 \% проживающие с партнером (в т. ч. в законном браке - 11 \%); по образованию 61,5 \% - имеющие среднее общее и среднее профессиональное образование, 38,5 \% - высшее образование; по месту жительства (68,7 \% проживающие в городе, 31,3 \% - в селе); по уровню дохода на члена семьи 56,8 \% - до 20000 руб., 43,2 \% - свыше 20000 руб. Общее количество опрошенных - 170 человек.

\section{Результаты и их обсуждение}

В ходе проведенного корреляционного анализа были выявлены следующие взаимосвязи (табл. 2). 


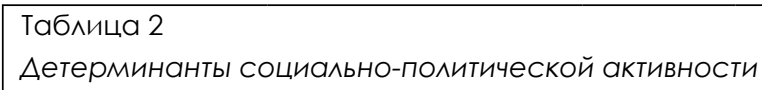

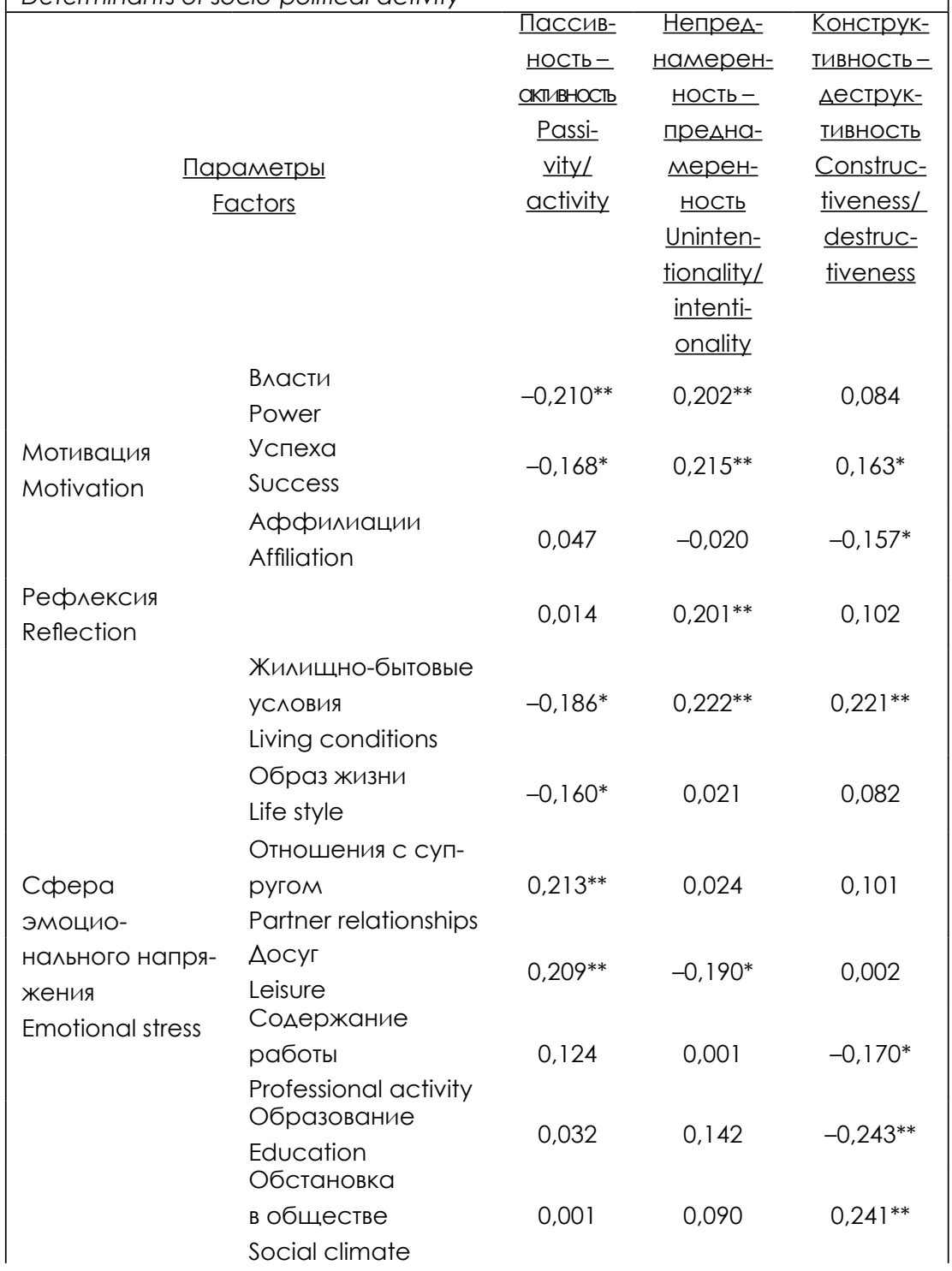




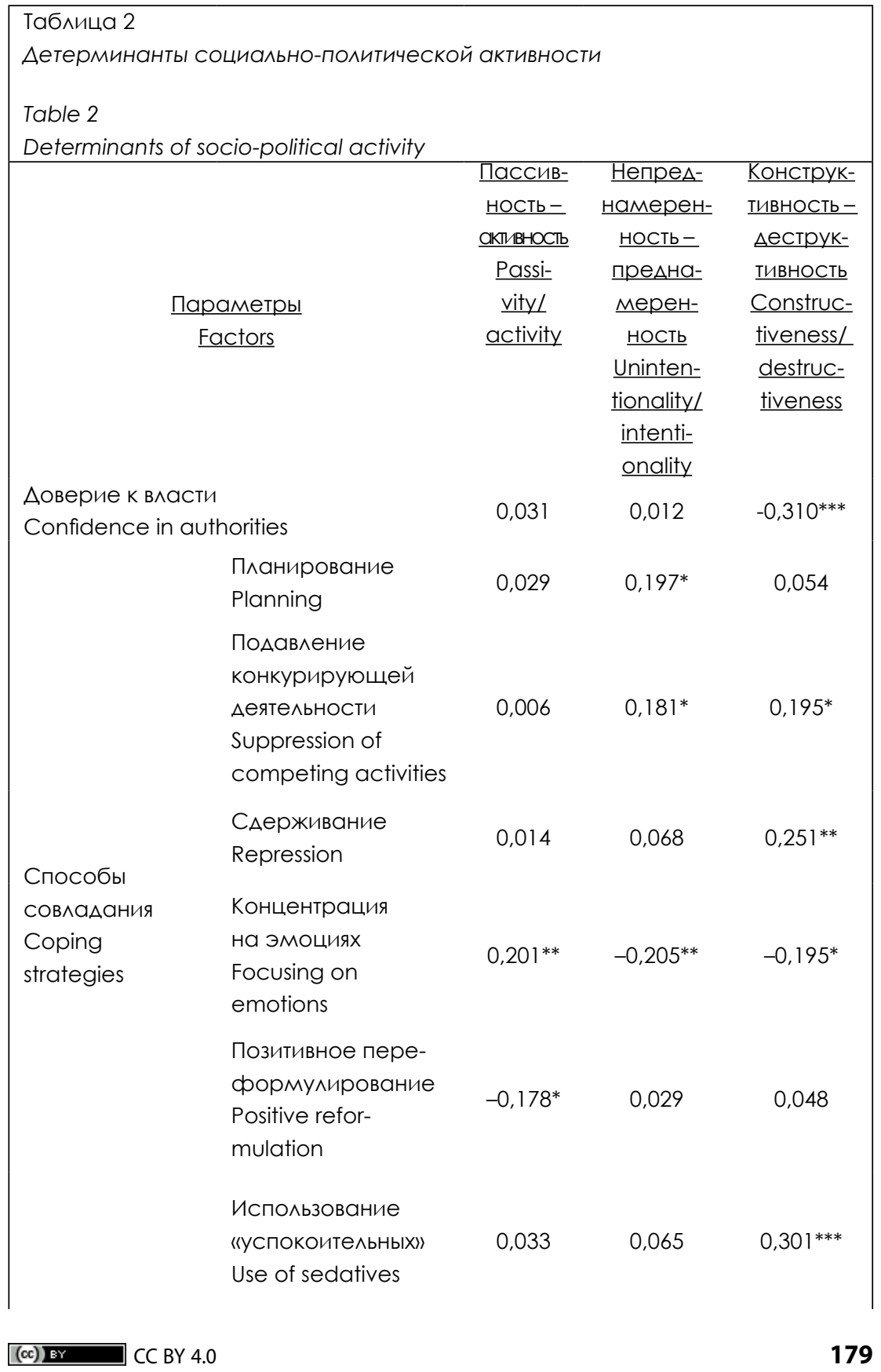




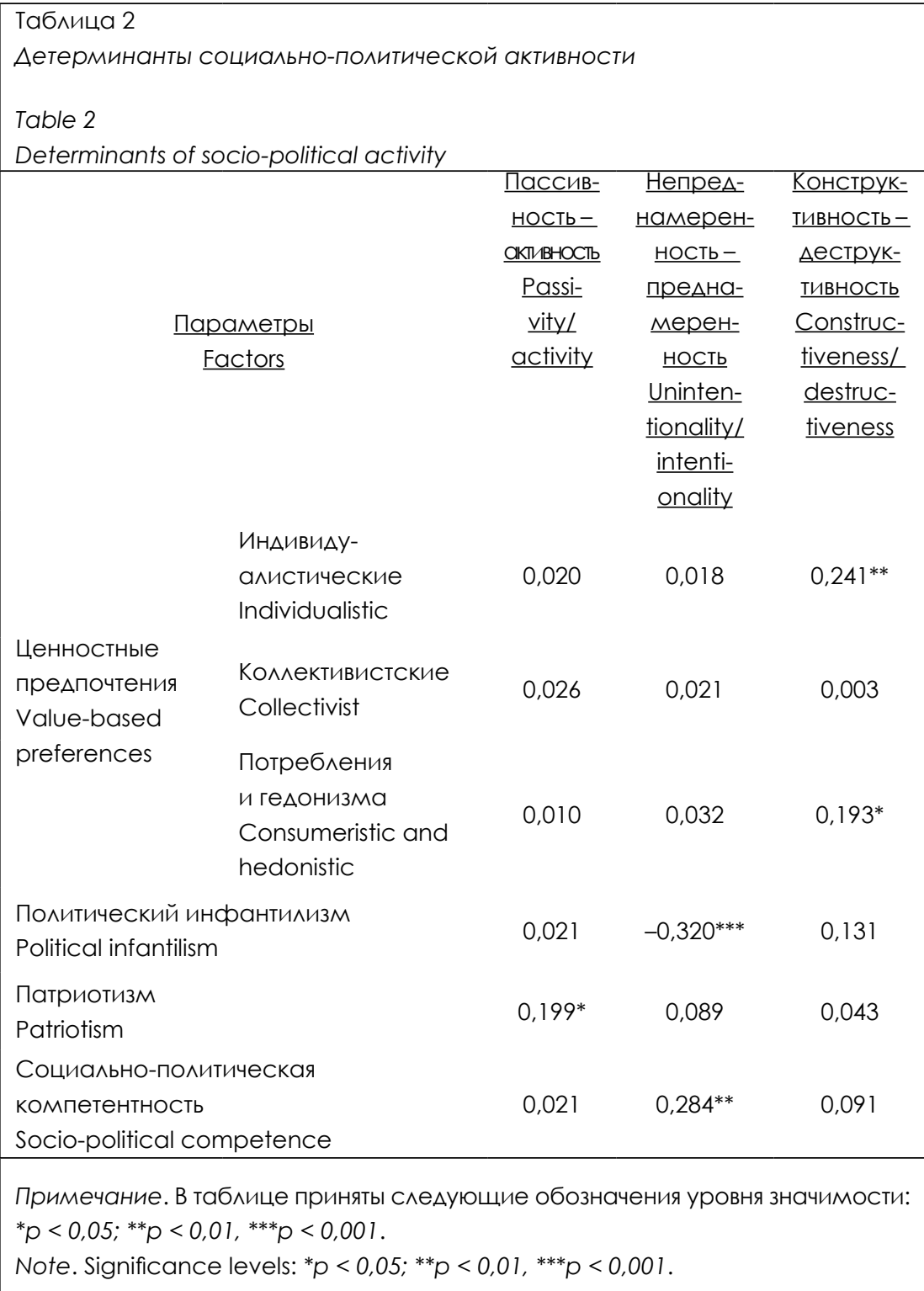

Полученные результаты исследования позволяют нам говорить о разнообразных субъектах социально-политической активности молодежи: 
Социально-политически активный субъект характеризуется невыраженной мотивацией к власти и успеху. Он не испытывает эмоционального напряжения, связанного с жилищно-бытовыми условиями и в целом, несмотря на неудовлетворенность в отношениях с супругом и возможностями проводить досуг, удовлетворен своим образом жизни. Социально-политически активный субъект склонен фокусироваться на неприятных эмоциях и не предпринимает попыток переосмыслить стрессовую ситуацию в позитивном ключе. Для него характерны преданность и любовь к своему отечеству.

Социально-политически пассивный субъект характеризуется выраженной мотивацией к успеху и власти. Он полностью удовлетворен отношениями с супругом и своим досугом, но испытывает эмоциональное напряжение, связанное с жилищно-бытовыми условиями и способом собственной жизнедеятельности. Ему не свойственно концентрироваться на возникающих эмоциях, а сложные и стрессовые ситуации он стремится переосмыслить и найти в них положительные стороны.

Для субъекта преднамеренной социально-политической активности свойственна мотивация к власти и успеху, неудовлетворенность жилищно-бытовыми условиями и удовлетворенность способами проведения досуга. Чаще он стремится подавить свои эмоции и спокойно обдумать дальнейшие действия, разработать дальнейшую стратегию поведения. Иногда в стрессовых ситуациях ему приходится переключаться на другие виды активности, с целью нивелирования последствий возникших неприятностей. Он обладает широким комплексом современных знаний о социально-политическом устройстве общества, умеет применять свои знания на практике, обладает качествами авторитета, склонен к рефлексии.

Для субъекта непреднамеренной социально-политической активности не свойственно желание подчинить окружающих своей воле и добиться общественного признания; они не склонны размышлять о своих переживаниях и своем поведении. Чаще всего они испытывают сильное неудовлетворение своими жилищно-бытовыми условиями, но в целом удовлетворены организацией досуга. Субъекты непреднамеренной социально-политической активности часто акцентируют свое внимание на эмоциях, неспособны переключиться и проанализировать возникшую ситуацию. Они обладают узким кругозором по вопросам социально-политической жизни общества, проявляют незрелость в решении социально-политических задач.

Конструктивную социально-политическую активность демонстрируют субъекты, стремящиеся быть в обществе других людей. Они испытывают потребность в создании теплых, доверительных, эмоционально значимых отношений с другими людьми, удовлетворены содержанием своей профессиональной деятельности и уровнем образования. Данные субъекты 
не погружаются в свои переживания и не концентрируются на эмоциях. Они понимают социально-политические процессы, происходящие в обществе, и испытывают доверие к власти и ее решениям.

Деструктивную социально-политическую активность демонстрируют субъекты, стремящиеся к успеху, неудовлетворенные жилищно-бытовыми условиями и обстановкой в обществе. К власти данные субъекты относятся без доверия, не видят ее эффективности и способности решать задачи общества. В системе ценностей на первый план у них выходят индивидуалистические ориентации, они склонны к гедонизму и потреблению. Часто сдерживают свое поведение для более подходящего момента, не спешат в решении возникших задач, для снятия эмоционального напряжения и улучшения самочувствия прибегают к алкоголю и успокоительным средствам.

\section{Выводы}

Системно-диахронический подход позволяет обозначить отношения и связи детерминант социально-политической активности в динамике и исторической последовательности их возникновения.

С этой целью в работе предложена модель социально-политической активности, отражающая степень включенности личности в систему социально-политических отношений, степень осознанности и преднамеренности ее проявления, а также форму влияния социально-политической активности на личность, общество и социально-политическую систему в целом.

Результаты эмпирического исследования детерминант социально-политической активности, проведенного с применением авторского опросника СПАМ, позволяет говорить о том, что мотивация детерминирует социально-политическую активность; при этом доминирование мотивации успеха и власти, с одной стороны, обусловливает низкий уровень социально-политической активности, а с другой стороны - ее преднамеренный характер. С увеличением мотивации аффилиации происходит деформация формы социально-политической активности в сторону ее конструктивности.

Социально-политическая активность обусловливается уровнем, сферами и способами совладания с эмоциональным напряжением. Неудовлетворенность жилищно-бытовыми условиями взаимосвязана с уровнем активности и обусловливает ее преднамеренный и деструктивный характер. Эмоциональное напряжение, связанное с содержанием работы и уровнем образования, детерминирует деструктивную социально-политическую активность. Концентрация на своих эмоциях, с одной стороны, увеличивает уровень активности, а с другой стороны, обусловливает ее преднамеренный и конструктивный характер.

Постепенный отход современной молодежи от коллективизма к индивидуализму с наличием признаков, характерных для общества потребления, 


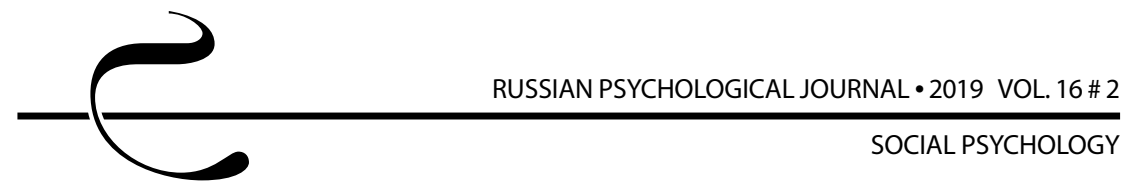

позволяет нам говорить о деформации социально-политической активности от конструктивной к деструктивной форме проявления.

Полученные результаты позволяют нам спрогнозировать и описать психологический портрет субъекта социально-политической активности, что, в свою очередь, делает возможным профилактику и коррекцию разного уровня и направленности форм деструктивной социально-политической активности современной молодежи.

\section{Благодарности}

Исследование выполнено за счет гранта Российского научного фонда (проект № 18-18-00298).

\section{Acknowledgements}

This study was supported by the Russian Foundation for Basic Research (project no. 18-18-00298).

\section{Литература}

Алфимова М. В., Трубников В. И. Психогенетика агрессивности // Вопросы психологии. 2000. № 6. С. 112-123.

Арендачук И. В. Динамика ценностно-смысловых характеристик социальной активности современной молодежи // Вестник Российского университета дружбы народов. Серия: Психология и педагогика. 2018. Т. 15, № 3. C. 287-307. DOI: 10.22363/2313-1683-2018-15-3-287-307

Баранова Г. В., Костенко В. В. Социально-политическая активность молодежных общественных организаций // В мире научных открытий. 2014. № 3-4 (51). C. 1717-1728.

Васильева Е. Н., Полтавская М. Б., Левковская Н. Г. Формирование социально-политической активности студенческой молодежи: социализирующие факторы и педагогические установки // Интернет-журнал Науковедение. 2015. T. 7, № 3 (28). C. 142. URL: http://naukovedenie.ru/PDF/123PVN315. pdf (дата обращения: 27.05.2019).

Грачева М. С. Политический протест современной молодежи в концептуальном осмыслении западной политологии // Вестник Московского государственного областного университета. Серия: История и политические науки. 2016. № 5. С. 138-142. DOI: 10.18384/2310-676X-2016-5-138-142

Егорова А. А. Построение ситуации собственного действия: способ действия и намерение // Культурно-историческая психология. 2010. № 3. C. 18-27.

Заграничный А. И. Ситуативные и мировоззренческие факторы социально-политической активности молодежи // Общество: социология, психология, педагогика. 2018. № 9. C. 67-71. DOI: 10.24158/spp.2018.9.13 
Зайцева И. А. Социально-политическая активность российской студенческой молодежи // Youth World Politic. 2016. № 1. С. 24-32.

Киричек А. И. К вопросу о дифференциации содержания категорий «политическая активность», «политическое поведение» и «политическое участие» // Общество: политика, экономика, право. 2011. № 3. С. 34-37.

Кожевников С. Н. Правовая активность граждан: Учебное пособие. Нижний Новгород: Тип. Нижегород. высш. школа МВД, 1994. 106 с.

Криворучко М. В., Щербакова К. Н. Особенности субъектных характеристик молодежи с разными формами политической активности // Вестник Омского университета. Серия: Психология. 2013. № 2. С. 5-13.

Куконков П. И., Куконков И. П. Методологические основания исследования социальной деструкции в постсоветской России // Конфликтология. 2013. № 1. С. 34-52. Куконков П. И., Лубяной М. С. Диагностика процесса трансформации социальных напряжений в социальную деструкцию: некоторые методологические подходы // Конфликты в социальной сфере: Сборник VII Всероссийской научно-практической и научно-методической конференции, 15-16 марта. Казань: Изд-во КНИТУ, 2013. С. 69-74.

Левкина Л. И. Взаимодействие органов местного самоуправления с местными сообществами. Проблемы, итоги // Азимут научных исследований: педагогика и психология. 2016. Т. 5, № 4 (17). С. 468-472.

Лысак И. В. Механизмы и последствия деструктивной деятельности человека. Ростов-на-Дону; Таганрог: Изд-во СКНЦ ВШ, Изд-во ТРТУ, 2006. 80 с.

Морозова Г. В. Студенческая молодежь: динамика политических интересов (региональный аспект) // Вестник Волгоградского государственного университета. Серия 4: История. Регионоведение. Международные отношения. 2015. № 6 (36). C. 127-134. DOI: 10.15688/jvolsu4.2015.6.16

Мулик А. Б., Антонов Г. В., Улесикова И. В., Шатыр Ю. А. Механизмы гендерного формирования деструктивного поведения и социальной активности человека // Вестник Волгоградского государственного университета. Серия 7: Философия. Социология и социальные технологии. 2016. № 4 (34). C. 89-99. DOI: $10.15688 /$ jvolsu7.2016.4.10

Панов В. И. Экопсихологические предпосылки изучения психической активности // Известия Саратовского университета. Новая серия. Серия Акмеология образования. Психология развития. 2014. Вып. 3. С. 214-223. Петровский А. В., Ярошевский М. Г. Основы теоретической психологии: Учебное пособие. М.: ИНФРА-М, 1998. 528 с.

Савастьина А. А., Осипова Л. Б. Социальная активность молодежи как условие динамичного развития общества // Современные проблемы науки и образования. 2015. № 2-2. URL: http://www.science-education.ru/ru/ article/view?id=22320 (дата обращения: 03.10.2018). 


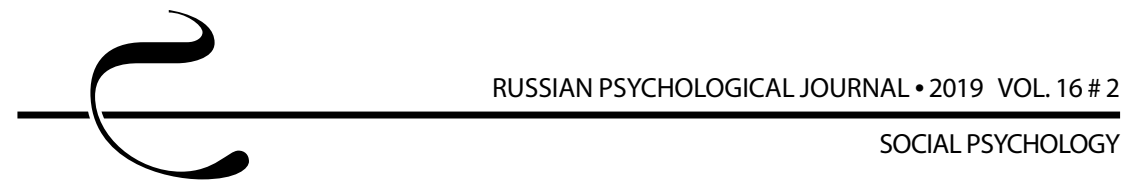

Слободчиков В. И., Исаев Е. И. Психология человека: Введение в психологию субъективности: Учебное пособие. 2-е изд., испр. и доп. М.: Изд-во ПСТГУ, 2013. $360 \mathrm{c}$.

Суходольский Г. В. Основы психологической теории деятельности. М.: Изд-во ЛКИ, 2008. 168 C.

Сысоева О. В., Куликова М. А., Малюченко Н. В., Тоневицкий А. Г., Иваницкий А. М. Генетические и социальные факторы в развитии агрессивности // Физиология человека. 2010. Т. 36, № 1. С. 48-55.

Усова Н. В. Применение системно-диахронического подхода в исследовании социально-политической активности личности // Азимут научных исследований: педагогика и психология. 2018а. Т. 7, № 4 (25). С. 365-368.

Усова Н. В. Разработка и апробация опросника социально-политической активности молодежи (опросник СПАМ) // Общество: социология, психология, педагогика. 2018b. № 12. C. 173-178. DOI: 10.24158/spp.2018.12.29

Федотова В. Русская апатия как противостояние хаосу // Политический класс. 2005. № 1. URL: http://www.intelros.org/lib/statyi/fedotova1.htm_дата обращения 03.09.2018).

Чолпонкулова Н. Т. Особенности самоотношения студенческой молодежи как проявлений ценностной ориентации и социальной активности // Вестник Кыргызско-Российского Славянского университета. 2018. Т. 18, № 5. С. 159-162.

Шамионов Р. М. Социализация личности: системно-диахронический подход // Психологические исследования. 2013. T. 6, № 27. URL: http://psystudy. ru/index.php/num/2013v6n27/782-shamionov27.html (дата обращения 03.09.2018).

Albertazzi D., Mueller S. Populism and liberal democracy: Populists in government in Austria, Italy, Poland and Switzerland // Government and Opposition. 2013. Vol. 48, Issue 3. P. 343-371. DOI: $10.1017 /$ gov.2013.12

Azzi A. E., Chryssochoou X., Klandermans B., Simon B. Identity and participation in culturally diverse societies: A multidisciplinary perspective. Chichester, United Kingdom: Wiley-Blackwell, 2011. DOI: 10.1002/9781444328158

Barrett M., Zani B. Political and civic engagement: Theoretical understandings, evidence and policies // Political and civic engagement: Multidisciplinary perspectives / M. Barrett, B. Zani (Eds.). New York: Routledge, 2015. P. 3-26.

Bot W., Verkuyten M. Evaluating the political organisation of Muslim citizens in the Netherlands: The role of political orientation, education and multiculturalism // Journal of Social and Political Psychology. 2018. Vol. 6, № 2. DOI: 10.5964/jspp.v6i2.901

Craig M. A., Richeson J. A. On the precipice of a "majority-minority" America: Perceived status threat from the racial demographic shift affects White 
Americans' political ideology // Psychological Science. 2014. Vol. 25, Issue 6. P. 1189-1197. DOI: $10.1177 / 0956797614527113$

Hoyt C. L., Parry M. Sociocultural and individual manifestations of sexual stigma: The role of political ideology and prejudice in discrimination against sexual minorities // Journal of Social and Political Psychology. 2018. Vol. 6, № 1. DOI: 10.5964/jspp.v6i1.810

Kaase M., Marsh A. Political action repertory // Political action: Mass participation in five western democracies / S. Barnes, M. Kaase (Eds.). Beverly Hills, CA: Sage Publications, 1979. P. 153-155.

\section{References}

Albertazzi, D., \& Mueller, S. (2013). Populism and liberal democracy: Populists in government in Austria, Italy, Poland and Switzerland. Government and Opposition, 48(3), 343-371. doi: 10.1017/gov.2013.12

Alfimova, M. V., \& Trubnikov, V. I. (2000). Psychogenetics of aggression. Voprosy psykhologii, 6, 112-123. (in Russ).

Arendachuk, I. V. (2018). Dynamics of value-meaning characteristics of social activity of modern youth. Vestnik Rossiiskogo universiteta druzhby narodov. Seriya: Psikhologiya i pedagogika (RUDN Journal of Psychology and Pedagogics), 15(3), 287-307. doi: 10.22363/2313-1683-2018-15-3-287-307 (in Russ).

Azzi, A. E., Chryssochoou, X., Klandermans, B., \& Simon, B. (2011). Identity and participation in culturally diverse societies: A multidisciplinary perspective. Chichester, United Kingdom: Wiley-Blackwell. doi: 10.1002/9781444328158

Baranova, G. V., \& Kostenko, V. V. (2014). Socio-political activity of youth public organizations. V mire nauchnykh otkrytii (In the World of Scientific Discoveries), 3-4(51), 1717-1728. (in Russ).

Barrett, M., \& Zani, B. (2015). Political and civic engagement: Theoretical understandings, evidence and policies. In M. Barrett \& B. Zani (Eds.), Political and civic engagement: Multidisciplinary perspectives (pp. 3-26). New York: Routledge.

Bot, W., \& Verkuyten, M. (2018). Evaluating the political organisation of Muslim citizens in the Netherlands: The role of political orientation, education and multiculturalism. Journal of Social and Political Psychology, 6(2). doi: 10.5964/ jspp.v6i2.901

Cholponkulova, N. T. (2018). Characteristics of students' self-relations as a manifestation of value orientations and social activities. Vestnik Kyrgyzsko-Rossijskogo slavyanskogo (Bulletin of the Kyrgyz-Russian Slavic University), 18(5), 159-162. (in Russ.).

Craig, M. A., \& Richeson, J. A. (2014). On the precipice of a "majority-minority" America: Perceived status threat from the racial demographic shift affects 


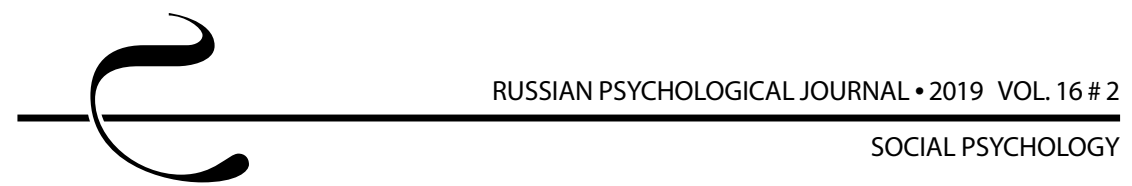

White Americans' political ideology. Psychological Science, 25(6), 1189-1197. doi: $10.1177 / 0956797614527113$

Egorova, A. A. (2010). Construction of situation of own action: The mode of action and intention. Kul'turno-istoricheskaya psikhologiya (Cultural-Historical Psychology), 3, 18-28. (in Russ.).

Fedotova, V. (2005). Russian apathy as an opposition to chaos. Political Class, 1. Retrieved from: http://www.intelros.org/lib/statyi/fedotova1.htm (in Russ.) Gracheva, M. S. (2016). Modern youth's political protest in conceptual comprehension of western politology. Vestnik Moskovskogo gosudarstvennogo oblastnogo universiteta. Seriya: Istoriya i politicheskie nauki (Bulletin of Moscow Region State University. Series: History and Political Sciences), 5, 138-142. doi: 10.18384/2310-676X-2016-5-138-142 (in Russ.).

Hoyt, C. L., \& Parry, M. (2018). Sociocultural and individual manifestations of sexual stigma: The role of political ideology and prejudice in discrimination against sexual minorities. Journal of Social and Political Psychology, 6(1), 364-382. doi: 10.5964/jspp.v6i1.810

Kaase, M., \& Marsh, A. (1979). Political action repertory. In S. Barnes \& M. Kaase (Eds.), Political action: Mass participation in five western democracies (pp. 153-155). Beverly Hills, CA: Sage Publications.

Kirichek, A. I. (2011). Differentiating the content of the categories of political activity, political behavior, and political participation. Obshchestvo: politika, ehkonomika, pravo (Society: Politics, Economics, Law), 3, 34-37. (in Russ.).

Kozhevnikov, V. V. (2016). Professional legal awareness in law enforcement. Sovremennoe pravo (Modern Law), 1, 5-17. (in Russ.).

Krivoruchko, M. V., \& Shcherbakova, K. N. (2013). Subject characteristics among youth with different forms of political activity. Vestnik Omskogo universiteta. Seriya "Psihologiya" (Omsk University Herald. Series "Psychology"), 2, 5-13. (in Russ.).

Kukonkov, P. I. (2014). Transformation of stress in the social space. Konfliktologiya (Conflictology), 4, 39-53. (in Russ.).

Levkina, L. I. (2016). Interaction of local governments with local communities: Problems and results. Azimut nauchnykh issledovanil: pedagogika i psikhologiya (Azimuth of Scientific Research: Pedagogy and Psychology), 5, 4(17), 468-472. (in Russ.).

Lysak, I. V. (2006). Mechanisms and consequences of human destructive activity. Rostov-on-Don; Taganrog: Izd-vo SKNTs VSH, Izd-vo TRTU. (in Russ.).

Morozova, G. V. (2015). Student youth: Dynamics of political interests (a regional aspect). Vestnik Volgogradskogo gosudarstvennogo universiteta. Seriya 4: Istoriya. Regionovedenie. Mezhdunarodnye otnosheniya (Science Journal of VolSU. History. Area Studies. International Relations), 6(36), 127-134. doi: 10.15688/ jvolsu4.2015.6.16 (in Russ.). 
Mulik, A. B., \& Antonov, G. V. (2016). Mechanisms of gender formation of destructive behavior and human social activity. Logos et Praxis, 4(34). Retrieved from https://cyberleninka.ru/article/n/mehanizmy-gendernogo-formirovaniyadestruktivnogo-povedeniya-i-sotsialnoy-aktivnosti-cheloveka (in Russ.)

Panov, V. I. (2014). Ecopsychological background for studying mental activity. Izv. Sarat. un-ta. Ser. Akmeologiya obrazovaniya. Psikhologiya razvitiya (Izvestiya of Saratov University. New Series. Series: Educational Acmeology), 3, 214-223. (in Russ.).

Petrovskii, A. V., \& Yaroshevskii, M. G. (1998). Fundamentals of theoretical psychology. Moscow: INFRA-M. (in Russ.).

Savast'ina, A. A., \& Osipova, L. B. (2015). Social activity of youth as a condition for the dynamic development of society. Modern problems of science and education, 2-2. Retrieved from http://www.science-education.ru/ru/article/ view?id=22320 (in Russ.)

Shamionov, R. M. (2013). Socialization of personality: A systemic diachronic approach. Psikhologicheskie Issledovaniya, 6(27). Retrieved from http://psystudy. ru/index.php/num/2013v6n27/782-shamionov27.html (in Russ.)

Slobodchikov, V. I. \& Isaev, E. I. (1996). Human psychology. Moscow. (in Russ.).

Sukhodol'skii, G. V. (2008). Fundamentals of the psychological theory of activity. Moscow: Izd-vo LKI. (in Russ.).

Sysoeva, O. V., Kulikova, M. A., Malyuchenko, N. V., Tonevitskii, A. G., \& Ivanitskii, A. M. (2010). Genetic and social factors in the development of aggression. Human physiology, 36(1), 48-55. (in Russ.).

Usova, N. V. (2018a). The development and testing of the Youth Social and Political Engagement Questionnaire (YSPE questionnaire). Obshchestvo: sotsiologiya, psikhologiya, pedagogika (Society: Sociology, Psychology, Pedagogy), 12, 173-178. doi: $10.24158 /$ spp.2018.12.29 (in Russ.)

Usova, N. V. (2018b). A systemic diachronic approach in the study of individuals' socio-political activities. Azimut nauchnykh issledovanil: pedagogika i psikhologiya (Azimuth of Scientific Research: Pedagogy and Psychology), 4(25), 365-368. (in Russ.).

Vasil'eva, E. N., Poltavskaya, M. B., \& Levkovskaya, N. G. (2015). Formation of social and political activity among students: Socialization factors and educational attitudes. Naukovedenie, 7, 3(28), 142. Retrieved from http://naukovedenie. ru/PDF/123PVN315.pdf (in Russ.)

Zagranichnyi, A. I. (2018). The situational and worldview factors in social and political involvement of youth. Obshchestvo: sotsiologiya, psikhologiya, pedagogika (Society: Sociology, Psychology, Pedagogy), 67-71. doi: 10.24158/ spp.2018.9.13 (in Russ.).

Zaitseva, I. A. (2016). Socio-political activity of Russian student youth. Youth World Politic, 1, 24-32. (in Russ.). 